\title{
Evaluasi Kecukupan Nutrisi Sapi Bali Dara Yang Dipelihara Di BPT-HMT Serading Kabupaten Sumbawa
}

\section{(Evaluation of the Adequacy of Nutrition for Bali Heifers Reared at BPT-HMT Serading, Sumbawa Regency)}

\author{
Oscar Y, Sofyan, M. Amin, S.H. Dilaga, Dahlanuddin dan Suhubdy \\ Faculty of Animal Science, University of Mataram \\ Jl. Majapahit 62. Mataram 83125 NTB. Telephone (0370) 633603; Fax (0370) 640592 \\ Email : oscary338@gmail.com
}

Diterima : 12 Oktober 2020/Disetujui : 02 Januari 2021

\begin{abstract}
ABSTRAK
Penelitian berjudul Evaluasi Kecukupan Nutrisi sapi Bali dara yang dipelihara di BPT-HMT Serading Kabupaten Sumbawa ini telah dilaksanakan selama 3 bulan dari bulan April hingga Juni 2019 di BPT-HMT Serading. Penelitian menggunakan 10 ekor sapi dara dengan bobot badan ratarata 146,86 $\pm 4,2 \mathrm{~kg}$ yang ditempatkan dalam sistem kandang kolektif yang dilengkapi bak pakan dan air minum. Pengambilan data untuk produksi hijauan menggunakan metode survey serta pengukuran dan pengamatan langsung dilapangan dengan menggunakan quadran dengan ukuran 1 $\mathrm{m} \times 1 \mathrm{~m}$. Penempatan quadran pada padang rumput dilakukan dengan cara acak sistematis sedangkan komposisi botani dilakukan, dengan metode pengukuran Summed Dominance Ratio (SDR) berdasarkan frekuensi (keseringan), berdasarkan density (kepadatan), berdasarkan area cover (penutupan tanah). Variabel yang diamati dalam penelitian ini meliputi pengamatan sistem pemeliharaan, jumlah dan jenis pakan yang diberikan, Produksi hijauan dan komposisi botani di padang penggembalaan dan pertambahan bobot badan ternak. Data yang diperoleh dalam penelitian ini dianalisis secara deskriptif (Mean dan Standart Deviasi). Hasil penelitian menunjukkan bahwa sistem pemeliharaan sapi dara bali yang dipelihara di HMT Serading adalah sistem semi intensif, pakan yang diberikan dalam kandang adalah rumput raja $(50,6 \%)$, lamtoro $(16,3 \%)$, jerami padi $(22,6 \%)$, dan jerami jagung $(10,5 \%)$. Pakan yang tersedia dipadang penggembalaan adalah rumput bintang, rumput para dan ilalang dan termasuk dalam komposisi botani padang penggembalaan yang kurang baik dengan kapasitas daya tampung 0,4 $\mathrm{UT} / \mathrm{Ha} / \mathrm{Tahun}$.
\end{abstract}

Kata Kunci : Sapi bali, Padang penggembalaan, Komposisi Botani, Serading, Sumbawa

\begin{abstract}
The research, entitled Evaluation of the Adequacy of Nutrition for Bali heifers reared at BPT-HMT Serading, Sumbawa Regency, has been conducted for 3 months from April to June 2019 at BPTHMT Serading. The study used 10 heifers with an average body weight of $146.86 \pm 4.2 \mathrm{~kg}$ which were placed in a collective pen system equipped with feed and drinking water tanks. Data collection for forage production used survey methods as well as direct field measurements and observations using a quadran with a size of $1 \mathrm{~m} \times 1 \mathrm{~m}$. The placement of the quadrant on the grasslands is done in a systematic random way, while the botanical composition is carried out, using the Summed Dominance Ratio (SDR) measurement method based on frequency (frequency), based on density, based on the area of cover (land cover). The variables observed in this study included observations of the maintenance system, the amount and type of feed given, forage production and botanical composition in the pasture land and the weight gain of livestock. The data obtained in this study were analyzed descriptively (mean and standard deviation). The results showed that the bali heifers reared in Serading forage was a semi-intensive system, the feed given in the pen was king grass $(50.6 \%)$, Leucaena $(16.3 \%)$, rice straw $(22.6 \%)$, and corn straw $(10.5 \%)$. The available feed in the grazing fields is star grass, para grass and thatch and is included in the poor botanical composition of pastures with a carrying capacity of $0.4 \mathrm{UT} / \mathrm{Ha} /$ year.
\end{abstract}

Keywords: Bali cattle, pasture, Botanical Composition, Serading, Sumbawa 


\section{PENDAHULUAN}

Ada 3 hal yang perlu diperhatikan dalam pemeliharaan ternak yaitu breeding, feeding, dan manajemen. Pakan memiliki pengaruh yang paling besar yaitu sekitar 60\%. Hal ini menunjukan bahwa walaupun potensi genetik ternak tinggi, namun bila pemberian pakan tidak memenuhi kebutuhan nutrisinya maka produksi yang tinggi tidak akan tercapai. Selain itu, pakan juga merupakan komponen produksi dengan biaya yang besar, yaitu dapat mencapai $60-80 \%$ dari total biaya produksi (Santosa, 2002).

Penyebab utama rendahnya produktivitas dari ternak sapihan sapi Bali adalah pola pemeliharaan serta manajemen ternak yang rendah dan kurang terarah, dimana peternak pada umumnya kurang memperhatikan mutu pakan, tata cara pemeliharaan, perkandangan dan penyakit sehingga pertumbuhan ternak pada umur pertumbuhan kurang optimum, menyebabkan sapihan sapi Bali betina dan jantan yang diharapkan mampu menjadi bibit indukan yang unggul dan pejantan yang unggul menjadi kurang optimal.

Pemenuhan kebutuhan ternak akan nutrisi yang cukup dan seimbang penting diperhatikan, karena hal ini merupakan salah satu faktor yang berpengaruh besar terhadap pertumbuhan dan produksi ternak. Potensi genetik ternak yang tinggi, apabila tidak diimbangi dengan pemberian pakan yang memenuhi kebutuhan nutriennya, maka produksi yang tinggi tidak akan tercapai. Kondisi ini nantinya dikhawatirkan memberikan respon kurang menguntungkan terhadap performan pertumbuhan ternak, respon ternak terhadap manipulasi yang diberikan, juga ikut menentukan hasil dari pejantan dan indukan yang berkualitas. Lebih lanjut Dahlanuddin et-al., 2016. Menyatakan bahwa kualitas pakan sangat berpengaruh terhadap pertumbuhan sapi Bali betina muda dan ternak sapi dengan bobot badan yang lebih besar dengan umur yang sama akan lebih cepat mencapai dewasa kelamin.

Balai Pembibitan Ternak dan Hijauan Makanan Ternak (BPTHMT) Serading merupakan salah satu lembaga di bawah dinas peternakan di Kabupaten Sumbawa yang mengelolah sistem pembibitan ternak dan pemeliharaan hijauan makanan ternak. Lokasi ini terletak khususnya di Desa Serading Kecamatan Moyo Hilir Kabupaten Sumbawa. BPTHMT memiliki luas sekitar 42,52 Ha dan tempat lokasi padang pengembalaan untuk melepas ternak. Jumlah ternak yang ada di BPT-HMT sekitar 194 ekor diantaranya 51 ekor betina dewasa, 4 ekor jantan dewasa, 
53 ekor betina muda, 5 ekor jantan muda dan 81 pedet lepas sapih. Sebagai salah satu pusat pembibitan ternak BPT-HMT Serading mempunyai tugas yang cukup penting sebagai salah satu tempat pembibitan Sapi Bali yang dapat menghasilkan bakalan pejantan dan indukan yang berkualitas.

Permasalahan utama dalam usaha peternakan adalah ketersediaan pakan hal inilah yang juga dialami oleh BPT-HMT serading, Pada kondisi tertentu ketersediaan hijauan pakan sangat terbatas sehingga kualitas dan kuantitas hijuaan pakan yang diberikan juga berfluktuatif tentunya ini juga berpengaruh terhadap produktifitas ternak yang dipelihara. Berdasarkan pemikiran diatas maka perlu dilakuan evaluasi kecukupan nutrisi untuk sapi bali lepas sapih sebagai calon indukan yang dipelihara di BPT-HMT serading. Tujuannya untuk mengetahui kecukupan nutrisi sapisapi bali betina calon indukan yang dipelihara di BPT-MT Serading

\section{MATERI DAN METODE PENELITIAN}

\section{Waktu dan Tempat}

Penelitian ini rencanannya dilaksanakan selama 3 bulan pada bulan April hingga Juni 2019, bertempat di BPT-HMT Serading Kabupaten Sumbawa

\section{Materi Penelitian}

Alat yang digunakan pada penelitian ini yaitu timbangan digital, parang, ember, tongkat ukur, dan pita ukur.

Materi yang digunakan pada penelitian ini yaitu anak sapi Bali betina yang telah lepas sapih yang rata-rata berumur 10 sampai 12 bulan,berjumlah 10 ekor, pakan (hijauan dan konsentrat).

\section{Metode Penelitian}

10 ekor sapi bali betina lepas sapih dengan berat badan rata-rata . $146.86 \pm 4.2$. diletakkan dalam kendang kelompok yang telah dilengkapi dengan tempat pakan dan minum, dan pada pagi hari dilepas di padang penggembalaan selama $2-3$ jam Pemberian pakan didalam kandang dilakukan 2 kali sehari. Penimbangan ternak dilakukan 1 kali seminggu pada waktu yang sama yaitu sebelum ternak diberi pakan selama 3 bulan.

Pengambilan data untuk produksi hijauan metode yang yang digunakan dalam penelitian ini adalah metode survey serta pengukuran dan pengamatan langsung dilapangan "Actual Weight Estimate" (Halls et al., 1964 dalam Susetyo (1980) yaitu dengan menggunakan petak ukur $1 \mathrm{~m}$ x $1 \mathrm{~m}$. Penempatan petak ukur pada 
padang rumput dilakukan dengan cara acak sistematis.

\section{Pengambilan Data Untuk} Komposisi Botani dilakukan, dengan metode pengukuran Summed Dominance Ratio (SDR) berdasarkan frekuensi (keseringan), berdasarkan density (kepadatan), berdasarkan area cover (penutupan tanah). Prosedur kerjanya sebagai berikut : 1) melakukan survei pendahuluan guna memahami bentuk dan gambaran lingkungan lahan pengamatan, 2) menggunakan bingkai kuadrat dalam pengambilan sampling plot. Bingkai kuadrat yang digunakan berukuran 1 $\mathrm{m} x 1 \mathrm{~m}$, 3) Pada daerah pengamatan dilakukan penempatan sampling plot secara sistematis berupa plot-plot dengan jarak 10 meter dengan arah Timur, arah Barat, arah Selatan, arah Utara dan masing-masing sebanyak 10 plot, 4) melakukan identifikasi dengan cara observasi jenis vegetasi, dan penyebaran jenis formasi yang ada pada setiap plot dan menentukan besar frekuensi, kerapatan dan dominasi setiap jenis dengan cara menghitung tiap vegetasi yang ada dalam setiap plot, 5) melakukan identifikasi jenis spesies hijauan dengan cara mencocokan jenis spesies yang ada pada buku, 6) melakukan pemotongan hijauan dengan jarak potong dari permukaan tanah $5 \mathrm{~cm}, 7$ ) hijauan yang sudah di potong dimasukan kedalam kantong plastik yang sudah diberi kode, 8) kemudian hijauan siap ditimbang untuk mengetahui berat segarnya.

\section{Variabel yang diamati}

Variabel yang diamti dalam penelitian ini adalah :

- Sistem pemeliharaan

- Jumlah pakan yang diberikan

- Jenis hijauan pakan dan porsinya.

- Produktifitas hijauan dan komposisi botani pada padang penggembalaan

- Kandungan nutrisi dari masingmasing jenis pakan.

- Kenaikan Berat Badan

\section{Analisis data}

Data yang diperoleh dalam penelitian ini dianalisi secara Deskriptif (Mean dan Standar Defiasi).

\section{HASIL DAN PEMBAHASAN}

Gambaran umum lokasi Penelitian Penelitian ini dilaksanakan di Balai Pembibitan Ternak dan Hijauan Makanan Ternak (BPT-HMT) Serading. BPT-HMT Serading merupakan salah satu lembaga di bawah dinas peternakan Propinsi NTB. Lokasi ini terletak khususnya di Desa Serading Kecamatan Moyo Hilir Kabupaten Sumbawa. BPTHMT Serading memiliki luas sekitar 42,52 Ha.

Secara umum sapi bali calon induk yang dipelihara di BPT-HMT 
Serading adalah sebanyak 34 ekor.

System pemeliharaan yang diterapkan yaitu semi intensif dimana ternak digembalakan pada pagi hari dengan durasi penggembalaan sekitar 2-3 jam perhari kemudian dikembalikan lagi ke kandang.
Pakan yang diberikan untuk sapi calon induk tersebut yakni rumput raja, lamtoro, jerami padi dan jerami jagung. Sedangkan untuk persentase komposisi botani pakan disajikan dalam Tabel 1.

Tabel 1. Komposisi Botani Pakan Yang Diberikan Di Kandang Selama Peneltian.

\begin{tabular}{clcc}
\hline Pengamatan Minggu Ke & Jenis Hijauan Pakan & Jumlah (kg) & Persentase (\%) \\
\hline \multirow{2}{*}{$6 \mathrm{~s} / \mathrm{d} 5$} & Rumput Raja & 160 & $100 \%$ \\
& Rumput Raja & 120 & 69 \\
& Jerami Jagung & 35 & 20 \\
& Lamtoro & 20 & 11 \\
& Rumput Raja & 0 & 0 \\
9 & Jerami Jagung & 20 & 12 \\
& Lamtoro & 120 & 88 \\
& Rumput Raja & 0 & 0 \\
\multirow{2}{*}{10} & Jerami Jagung & 100 & 67 \\
& Lamtoro & 50 & 33 \\
& Rumput Raja & 0 & 0 \\
& Jerami Padi & 50 & 50 \\
& Jerami Jagung & 50 & 50 \\
& Rumput Raja & & 69 \\
& Jerami Padi & 70 & 58 \\
& Jerami Jagung & 50 & 42 \\
\hline
\end{tabular}

Sumber : Data primer diolah 2019

\section{Konsumsi pakan}

Pemberian pakan untuk sapi bali calon induk pada saat dikandangkan bervariasi mulai dari jumlah dan jenis pakan. Hal ini disesuaikan dengan ketersediaan pakan yang ada. Karena saat ini adalah musim kemarau, maka penyediaan pakan harus benar-benar disesuaikan agar ternak yang lain tidak kekurangan pakan. Pada minggu pertama sampai dengan minggu ke-5 pakan utama yang diberikan adalah $100 \%$ hanya rumput raja. Mulai minggu ke-6 sampai minggu ke-8 pemberian rumput raja mulai dikurangi namun ditambah dengan pemberian jerami jagung dan lamtoro dengan persentase berturutturut sekitar $69 \%, 20 \%$ dan $11 \%$. Dikarenakan ketersediaan rumput raja mulai menipis, maka pada minggu ke-9 pemberian rumput raja dihentikan dengan alasan kurangnya ketersediaan. Sebagai pengganti rumput raja petugas menyiasati 
dengan memberikan jerami jagung dalam jumlah yang banyak ditambahkan dengan pemberian jerami padi dan lamtoro.

\section{Pengukuran produksi padang penggembalaan}

$$
\text { BPT-HMT }
$$

Serading

menerapkan system pemeliharaan semi intensif dalam memelihara calon indukan. Dimana ternak tidak hanya dikandangkan melainkan juga dibiarkan merumput pada pagi hari dengan durasi sekitar 2-3 jam perhari. Ternak-ternak tersebut digembalakan pada padang penggembalaan buatan dengan luas lahan 1,5 ha yang dibagi menjadi 3 bagian (paddock) yang ditanami jenis rumput yang sama yaitu rumput bintang dan rumput para. Untuk mengetahui produksi rumput pada paddock tersebut maka dilakukan pengukuran dengan menggunakan metode Actual Weight Estimate" yaitu menggunakan quadran dengan ukuran $1 \mathrm{~m} \times 1 \mathrm{~m}$.

Berdasarkan hasil pengamatan komposisi botani padang penggembalaan yang dilihat dari aspek frekuensi (keseringan), pasture yang diukur didominasi oleh rumput bintang dengan persentase frekuensi sebesar 62,5\%. Kemudian disusul oleh rumput para sebesar $35 \%$ dan yang terakhir adalah ilalang dengan persentase frekuensi sebesar $12,5 \%$.

Tabel 2. Pengukuran produksi biomassa

\begin{tabular}{ccccc}
\hline $\begin{array}{c}\text { Sampel } \\
\text { pelemparan } \\
\text { kuadran }\end{array}$ & $\begin{array}{c}\text { Produksi berat } \\
\text { segar (g) per } \\
\mathbf{0 , 2 5} \mathbf{~ m 2}\end{array}$ & $\begin{array}{c}\text { Produksi berat } \\
\text { segar (kg) per } \\
\mathbf{~ m 2}\end{array}$ & $\begin{array}{c}\text { Produksi berat } \\
\text { segar (kg) per } \\
\text { ha }\end{array}$ & $\begin{array}{c}\text { Produksi } \\
\text { bahan kering } \\
\text { (kg) per ha }\end{array}$ \\
\hline 1 & 350 & 1,4 & 14000 & 4200 \\
2 & 400 & 1,6 & 16.000 & 4800 \\
3 & 600 & 2,4 & 24.000 & 7200 \\
4 & 200 & 0,8 & 8000 & 2400 \\
5 & 500 & 2 & 20.000 & 6000 \\
\hline
\end{tabular}

Sumber data diolah 2019

Dari 3 tempat penggembalan ternak yang terdapat di BPT-HMT Serading produksi biomassa pasture diambil pada pasture yang masih utuh (belum dilakuakan penggembalaan ternak) terlihat bahwa produksi ratarata biomasa di lokasi pengambilan sampel dengan 5 kali cuplikan adalah $1640 \mathrm{gr} / \mathrm{m}^{2}$. Dengan jenis rumput yang dominan adalah rumput bintang sebanyak $62,5 \%$, kemudian diikuti oleh rumput para sebanyak $25 \%$ dan sisanya $12,5 \%$ adalah alang-alang.

Kondisi tersebut menunjukan padang penggembalaan di lokasi penelitian belum ideal, karena padang penggembalaan yang ideal proporsi 
antara rumput dan leguminosa adalah 60\% : 40\% (Saragih, 2009). Hal ini juga didukung oleh Junaidi (2010) bahwa kualitas Padang penggembalaan tergolong baik apabila proporsi antara rumput dibanding legume adalah sebanyak 3 : 2, dapat dinyatakan bahwa kondisi padang penggembalaan di di BPTHMT Serading masih tergolong kurang baik.

\section{Daya Tampung Ternak}

Berdasarkan pengukuran produksi pastura pada tabel 2 diatas dapat diperkirakan daya tampung ternak yang dapat dipelihara di padang penggembalaan BPT-HMT Serading dengan simulasi contoh perhitungan sebagai berikut :

Bila produksi hijauan segar per meter2 $=1640$ gram dan proper use $=$ $45 \%$, maka jumlah hijauan tersedia per $\mathrm{m} 2$ adalah $45 \%$ × $1640 \mathrm{~g}=738$ $\mathrm{g} / \mathrm{m} 2$ atau diperkirakan $7380 \mathrm{~kg} / \mathrm{ha}$. Mengingat adanya musim kemarau yang panjang, periode istirahat padangan juga panjang untuk daerah tropik, periode istirahatnya adalah rata-rata 70 hari, kemudian setelah dipakai untuk penggembalaan selama 30 hari. Pada prakteknya pengaturan penggembalaan di daerah tropic memerlukan penelitian dan pengalaman daerah. Rerata berat badan sapi yang digunakan dalam penelitan ini adalah $146 \mathrm{~kg}$ Seekor sapi yang membutuhkan hijauan segar sebanyak $14.6 \mathrm{~kg} /$ hari akan mengkonsumsi hijaun segar sebanyak $30 \times 12 \times 14.6 \mathrm{~kg}=5256 \mathrm{~kg}$ hijauan segar yang harus disediakan tanah seluas $=5256 / 7380$ ha $=0,71$ ha. Kebutuhan luas tanah per tahun dihitung dengan menggunakan rumus Viosin (1959), yang disitasi oleh Soedomo R., (1985) yaitu :

$$
(y-1) s=r
$$

Keterangan :

$\mathrm{y}=$ angka perbandingan luas tanah yang diperkirakan seekor sapi per tahun.

$\mathrm{s}=$ periode stay merumput $\mathrm{r}=$ periode rest atau istirahat missal periode istirahat padangan tropic adalah 70 hari dengan periode merumput sapi selama 30 hari tiap rotasi maka dengan rumus viosin :

$$
\begin{aligned}
& (\mathrm{y}-1) \mathrm{s}=\mathrm{r} \\
& (\mathrm{y}-1) 30=70 \\
& \mathrm{y}=70 / 30+1 \\
& =2,3+1 \\
& =3,3
\end{aligned}
$$

Maka kebutuhan luas tanah pertahun adalah :

$3,3 \times 0,71$ ha/ekor/tahun $=2,3$ ha/ekor/tahun. Atau 1 ha dapat menampung 0,4 UT/tahun.

Daya tampung padang penggembalaan BPT-HMT Serading Kabupaten Sumbawa ini masih pada kisaran yang umum dimiliki oleh padang penggembalaan alam tropis (0,14 - 0,5 UT/ha/th; McIllroy, 1977 yang disitasi oleh Damri,2009). 
Namun demikian, nilai daya tampung ini lebih rendah dari nilai daya tampung padang penggembalaan yang ideal yaitu sebesar 2,5 UT/ha/th.

$$
\text { Reksohadiprodjo }
$$

menyatakan bahwa suatu padang penggembalaan dinyatakan produktif apabila minimal mempunyai daya tampung 2,5 UT/ha/tahun dengan demikian bahwa kapasitas tampung padang penggembalaan BPT-HMT
Serading masih tergolong rendah (hanya $0.4 \mathrm{UT} / \mathrm{ha} /$ tahun), hal ini diduga disebabkan oleh faktor komposisi botanis masih didominasi oleh rumput dan tidak ada leguminosa dan Gulma, sedangkan padang penggembalaan yang dikatagorikan baik bila mempunyai komposisi botanis yang ideal, dalam hal ini memiliki komposisi spesies hijauan rumput $60 \%$ dan leguminosa $40 \%$.

\section{Pertambahan Bobot Badan Harian (PBBH)}

Tabel 3. Pertambahan Bobot Badan Harian (PBBH)

\begin{tabular}{lcccc}
\hline No & No sapi & Umur & BB awal & BB akhir \\
\hline $\mathbf{1}$ & 850 & $24-30$ bulan & 140,5 & 147,5 \\
$\mathbf{2}$ & 614 & $24-30$ bulan & 139,5 & 149 \\
$\mathbf{3}$ & 825 & $24-30$ bulan & 146,5 & 156,5 \\
$\mathbf{4}$ & 940 & $24-30$ bulan & 147,5 & 157 \\
$\mathbf{5}$ & 926 & $24-30$ bulan & 149 & 160,5 \\
$\mathbf{6}$ & 775 & $24-30$ bulan & 150,5 & 162,5 \\
$\mathbf{7}$ & 630 & $24-30$ bulan & 143 & 154 \\
$\mathbf{8}$ & 723 & $24-30$ bulan & 152 & 159,5 \\
$\mathbf{9}$ & 894 & $24-30$ bulan & 148,5 & 159,5 \\
$\mathbf{1 0}$ & 893 & $24-30$ bulan & 151,5 & 163,5 \\
\hline \multicolumn{7}{r}{} & Total & 1468,5 & 1569,5 \\
\hline
\end{tabular}

Sumber: Data Primer diolah 2019

Penimbangan ternak rata Pertumbuhan Bobot Badan dilakukan 3 kali yakni pada awal Harian (PBBH) sapi bali calon induk penelitian, bulan kedua dan akhir penelitian. Setelah melakukan adalah sebesar $0,11 \mathrm{~kg}$ dengan perhitungan sebagai berikut :

penimbangan maka didapatkan rata-

$$
\begin{gathered}
\text { PBBH }=\frac{\text { Bobot badan akhir }- \text { Bobot badan awal }}{\text { Lama penggemukan }} \\
\text { PBBH }=\frac{156,95-146,85}{90 \text { hari }}=0,11 \mathrm{~kg}
\end{gathered}
$$




\section{Perbandingan kebutuhan dan konsumsi Energi dan Protein sapi bali calon induk di BPT-HMT Serading}

Table 4. Kebutuhan dan Konsumsi Energi dan Protein sapi Bali calon induk di BPTHMT

\begin{tabular}{|c|c|c|c|c|c|c|c|c|}
\hline \multirow[b]{2}{*}{ No } & \multirow[b]{2}{*}{$\begin{array}{c}\text { BB } \\
\text { awal }\end{array}$} & \multicolumn{2}{|c|}{ Kebutuhan } & \multicolumn{2}{|c|}{ Konsumsi } & \multirow[b]{2}{*}{$\begin{array}{l}\text { Bobot } \\
\text { Akhir }\end{array}$} & \multirow[b]{2}{*}{$\begin{array}{c}\text { PBBH } \\
\text { (kg) }\end{array}$} & \multirow[b]{2}{*}{ Ket } \\
\hline & & $\begin{array}{c}\text { ME } \\
\text { (Kcal/kg) }\end{array}$ & $\begin{array}{l}\text { PK } \\
\text { (g) }\end{array}$ & $\begin{array}{c}\text { ME } \\
\text { (Kcal/kg) }\end{array}$ & $\begin{array}{l}\text { PK } \\
\text { (g) }\end{array}$ & & & \\
\hline 1 & 146 & 1,77 & 189,72 & 2,91 & 251 & 157 & 0,11 & Kon $>$ keb \\
\hline 2 & 146 & 1,77 & 189,72 & 2,91 & 251 & 157 & 0,11 & Kon $>$ keb \\
\hline 3 & 146 & 1,77 & 189,72 & 2,91 & 251 & 157 & 0,11 & Kon $>$ keb \\
\hline 4 & 146 & 1,77 & 189,72 & 2,91 & 251 & 157 & 0,11 & Kon $>$ keb \\
\hline 5 & 146 & 1,77 & 189,72 & 2,91 & 251 & 157 & 0,11 & Kon $>$ keb \\
\hline 6 & 146 & 1,77 & 189,72 & 2,91 & 251 & 157 & 0,11 & Kon $>$ keb \\
\hline 7 & 146 & 1,77 & 189,72 & 2,91 & 251 & 157 & 0,11 & Kon $>$ keb \\
\hline 8 & 146 & 1,77 & 189,72 & 2,91 & 251 & 157 & 0,11 & Kon $>$ keb \\
\hline 9 & 146 & 1,77 & 189,72 & 2,91 & 251 & 157 & 0,11 & Kon $>$ keb \\
\hline 10 & 146 & 1,77 & 189,72 & 2,91 & 251 & 157 & 0,11 & Kon $>$ keb \\
\hline
\end{tabular}

Sumber : Data Primer diolah 2019

Hasil perhitungan kebutuhan dan konsumsi pakan sapi bali calon induk yang dilakukan dengan cara interpolasi menunjukkan bahwa kebutuhan energy dan protein untuk sapi bali calon induk dengan BB ratarata $146 \mathrm{~kg}$ adalah sebesar 1,77 $\mathrm{kcal} / \mathrm{kg}$ dan 189.72 g. dan hasil perhitungan konsumsi pakan didapatkan hasil energy dan protein sebesar $2,91 \mathrm{kcal} / \mathrm{kg}$ dan $251 \mathrm{~g}$. hal ini berarti bahwa nilai konsumsi pakan lebih besar daripada kebutuhan artinya Energi dan Protein sudah terpenuhi. Hal ini dibuktikan dengan adanya pertambahan bobot badan harian $(\mathrm{PBBH})$.

\section{KESIMPULAN DAN SARAN}

\section{Kesimpulan}

1. Sistem pemeliharaan sapi bali betina muda calon induk di BPTHMT Serading adalah dengan sistem semi intensif dengan pertambahan bobot badan harian sapi bali betina calon induk sebesar $0,11 \mathrm{~kg}$.

2. Pakan yang diberikan saat dikandang adalah rumput raja $(50,6 \%)$, lamtoro $(16,3 \%)$, jerami $(22,6 \%)$ padi dan jerami jagung (10,5\%), sedangkan pakan yang tersedia dipadang penggembalaan adalah rumput bintang, rumput para dan ilalang dan termasuk dalam komposisi botani padang penggembalaan yang kurang baik dengan kapasitas daya tampung 0,4 UT/Ha/Tahun. 


\section{Saran}

1. Untuk meningkatkan kualitas ternak yang dihasilkan maka perlu rasionalisasi jumlah ternak, ketersediaan pakan dan luas areal padang penggembalaan.

2. Perlu peningkatan kualtias hijaun dipadang penggembalaan dengan penanaman leguminosa.

\section{DAFTAR PUSTAKA}

Dahlanuddin, B T Yuliana., Oscar Y., T Panjaitan, M J Halliday, and H M Shelton . 2016. Increasing Fattening Performance of bali cattle by Improving Post Weaning Growth Throught Suplementation with Sesbania grandiflora. (Proceedings) The 17th Asian-Australian of Animal Production Sociates Animal Conress.

Damri, 2009. Produksi dan Kandungan Nutrien Hijauan Padang Penggembalaan Alam Di Kecamatan Lore Utara, Kabupaten Poso. Jurnal. Agroland 16 (4) : 296 - 300 .

Junaidi M, Sawn D. 2010. Keragaman botanis dan kapasitas tampung padang penggembalaan alam di Kabupaten Yapen. Jurnal Ilmu Peternakan 5(2):92- 97
Reksohadiprodjo S. 1994. Produksi Tanaman Hijauan Makanan Ternak Tropik. BPFE, Yogyakarta.

Santosa, 2002. Tata Laksana Pemeliharaan Ternak Sapi. Penebar Swadaya Jakarta.

Saragih EW, Tero NK. 2009. Potensi tiga padang penggembalaan yang berbeda di Kabupaten Manokwari. Jurnal Ilmu Peternakan 4 (2):53-60.

Soedomo R., 1985. Produksi Hijauan Makanan Ternak Tropik. BPFE Yogyakarta.P.185

Susetyo S. 1980. Padang Penggembalaan. Depertemen Ilmu Makanan Ternak, Fakultas Peternakan, IPB Bogor, Bogor 